\title{
CORRESPONDENCE
}

Correspondents are asked to be brief

Confidential Information and Cervical Cytology

J. C. McClure Browne, F.R.c.o.G. . . . . . 620

Ingested Foreign Bodies in Childhood

W. M. Brown, F.R.C.S.ED.; P. F. Pearson, M.B., and G. R. Smerdon, M.B.; R. T. Bur-

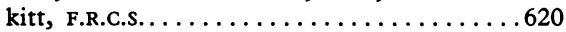

General Anaesthesia

M. P. Coplans, F.F.A. R.C.s. . . . . . . .6621

Virus-free Blood?

H. B. M. Lewis, F.R.C.PATh. . . . . . .6621

Cause of Death

V. H. Bowers, F.R.C.PATH. . . . . . . . .6621

Climate in the Theatre

G. C. Fraser, F.R.C.S...

Screening for Spastics

R. C. Mac Keith, F.R.C.P.; D. B. Brown

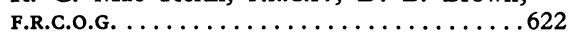

Availability of Cadaveric Kidneys

J. S. Garfield, F.R.C.S. . . . . . . . . . .622

V.D. Statistics

L. Watt, M.D...............623
Provision for the Mentally Handicapped

Ann Shearer, B.A.................623

Pregnancy Testing

A. B. Giles.................623

Prolonged Fever in Bacterial Meningitis

R. J. Fallon, M.D.............6623

Caroli's Disease

J. G. McNulty, F.F.R. . . . . . . . . . .623

Operations for Obesity

R. M. Baddeley, F.R.C.s. . . . . . . . . . 624

Diagnosis of Established Deep Vein

Thrombosis

J. G. Murray, F.R.C.s.; P. A. Griffiths and

S. Talbot, M.R.C.P...............624

Epidemic Keratoconjunctivitis

I. W. Payne, F.R.C.S........

Obesity and Smoking Habits

R. W. Howell, F.M.R, M.B.C..........625

Cot Deaths

O. Englander, M.D.... .

Anaesthesia for Cardioversion

H. Ikram, M.R.C.P., and A. P. Rubin,

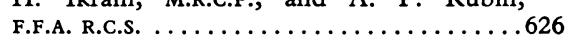

Handicapped Children in Preschool Playgroups

Annette S. Raikes, M.R.C.S...........626

Breast-milk Jaundice and Oral Contraceptives

G. H. Lathe, F.R.C.PATH. . . . . . . . . . . 626

Thiopropazate Hydrochloride in Persistent Dyskinesia

K. Singer, M.R.C.P.ED., D.P.M., and M. N.

Cheng, M.B..................626

Seat-belt Fasteners

K. E. Jolles, M.R.c.s. . . . . . . . . . . 626 Casualties

P. N. Dixon, D.P.H., and A. F. Morris . . . . .626 Fire-fighting Equipment

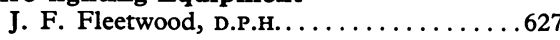
Undescended Testis

V. A. J. Swain, F.R.c.s. . . . . . . . . . . 6627

Pensions and the Abatement Rule

F. M. Sandford, F.F.A. R.C.S. . . . . . . .627

Hospital Staff Appointments

Bhim S. Pandhi, M.R.C.P..........627

\section{Confidential Information and Cervical Cytology}

SIR,-Dr. D. Mary Pack (6 November, p. 364) raises a number of pertinent questions about the form used in the national cervical cytology scheme, and as chairman of the committee on gynaecological cytology that has throughout been consulted by the Department of Health and Social Security I can assure her that the national recall scheme was elaborated with considerations of confidentiality in the forefront of our minds.

The N.H.S. central register at Southport operates as the central clearing house for the dissemination to executive councils of information about the reacceptance of patients in new areas following removal, and about patients' deaths, embarkations, enlistments, etc. It does not record patients' current addresses nor the names of their doctors, which are noted locally by the executive councils. It is maintained by the Registrar General on an agency basis for the Department of Health anc Social Security, and its primary purposes are to facilitate the appropriate distribution of patients' records and to assist in regulating capitation payments to general practitioners.

The Government's intention to introduce routine periodic recall for cervical cytology was foreshadowed when the screening service was announced in 1966. In the national recall scheme the use of the N.H.S. central register affords the possibility, not otherwise attainable, of getting in touch after an interval of years with a woman who has had a previous test, even though she may have moved to a new area, always provided she has registered with a general practitioner. Though at first sight the inclusion of maiden names may seem unnecessary it is most useful for the central register to facilitate identification of those women whose N.H.S. number has been omitted or incorrectly stated on the cytology report forms. Without such identification, of course, a woman might be deprived of the benefit of recall.
An important point that needs to be stressed is that the national scheme is so devised that no woman would be approached with a view to a follow-up test without her general practitioner being given the opportunity first of advising against the issue of the recall invitation.

It has been established on epidemiological grounds that women in social classes IV and $\mathrm{V}$ are more likely to develop invasive carcinoma of the cervix than are women in social classes I and II, and the same is true of married (and divorced) women as opposed to single women, and of parous as opposed to nulliparous women. Information about marital status, parity, and the husband's occupation makes it possible, therefore, to evaluate the degree of success or otherwise in reaching those most at risk. Such evaluation would of course be done on a statistical basis and the anonymity of the individual therefore would not be endangered. Incidentally, these two items of information have been included in these forms since 1966, and it seems sadly true from results so far obtained that those most at risk have been most likely to fail to respond.

I know that the Department of Health and Social Security and the Register General are concerned that there should be the utmost security in dealing with personal information. Nothing is sent to the central register which is not necessary for the recall scheme, and the scheme could not be operated effectively without using the register. The greatest attention is paid by the register to the confidentiality of these records.-I am, etc.,

J. C. MCClure Browne Committee on Gynaecological Cyairman,

University of London,

Institute of Obstetrics and Gynaecology, Hammersmith

\section{Ingested Foreign Bodies in Childhood}

SIR,-Mr. Lewis Spitz, in his excellent article on management of ingested foreign bodies in childhood ( 20 November, p. 469), states that a congenital anomaly, stenosis, or an annular pancreas may be responsible for failure of progression in stomach or duodenum. With regard to coins, I submit that the possibility of impaction at a normal pylorus may be another indication for surgical removal.

A healthy boy aged 6 swallowed a sixpenny piece (old coinage). Lack of progression in the stomach was noted daily by $x$-ray examination. $\mathrm{He}$ was symptomless until the sixth day, when all the symptoms and signs of a very high obstructive lesion suddenly developed. At operation I found the coin firmly impacted at the pylorus, at right angles to the pyloric axis, with considerable stomach dilatation. No difficulty was experienced in extracting the coin, and both convalescence and recovery were uneventful.

One wonders in small coin cases if a “minimum period of 10-12 days' observation before surgery is recommended" is not rather sanguine advice.-I am, etc.,

Hereford

W. MOIR BROWN

SIR,-Mr. Lewis Spitz's article on the management of ingested foreign bodies in childhood (20 November, p. 469) came as welcome reading as this subject is ill covered by standard textbooks, though it is a common problem. However, may we make the following points about the early management of these cases in accident departments.

Mr. Spitz implies that all children suspected of ingesting foreign bodies be $x$ rayed. This is needless exposure and an added burden to accident $x$-ray departments, a subject discussed at length recently. If the child is $x$-rayed we feel it is most im- 